\title{
Educational Programme for Pregnant Women About Zika Virus Infection in Benha City
}

\author{
Nehad Ahmed Ibrahim Zahra ${ }^{1}$ \\ ${ }^{1}$ Lecturer of Community Health Nursing, Benha University, Egypt \\ Correspondence: Nehad Ahmed Ibrahim Zahra, Lecturer of Community Health Nursing, Benha University, \\ Egypt.
}

Received: April 16, 2018

Accepted: May 14, 2018

Online Published: May 24, 2018

doi:10.20849/ijsn.v3i2.388

URL: https://doi.org/10.20849/ijsn.v3i2.388

\begin{abstract}
Background: Zika virus has potential to cause a pandemic so it becomes a major public health concern worldwide. Even if its effect on adults is commonly mild, Zika creates expressive risks for developing fetuses of infected women during pregnancy. The present study is quasi-experimental study aiming to examine the impact of Zika Virus Infection educational program for pregnant women on their knowledge, attitude and practice before and after applying for the program.

Setting: The study was performed at antenatal clinics in maternal and child health care center at Benha city from the beginning of August 2015 until October2015. The study sample consisted of105 pregnant women simple randomly included in the study. The data was collected through a structured Interviewing questionnaire for the mother to assess the level of women's knowledge attitude and reported practice related to ZIK virus were assessed before and after the program. The results revealed that there was a significant improvement in the nurses' knowledge score about Meaning, causative agent, Vaccine, symptoms, complications, investigations, and management of Zika virus; moreover, there was an improvement in total reported practices about Zika tends to rise.

Conclusion: There was an improvement in knowledge, attitude, and practice of the participant's post-program. Based on the results of the study recommended that: Health education to pregnant women about the Zika virus should be included in the antenatal health education program as well as the need for additional public health messaging to avoid it.
\end{abstract}

Keywords: Zika virus, pregnant women

\section{Introduction}

Zika infection can spread for the most part by daytime-dynamic Aedes mosquitoes. A pregnant mother can pass it to her child amid pregnancy or around the season of birth. It can spread through sexual contact. There have additionally been reports that the infection has spread through blood transfusions. There have been episodes of Zika infection in the United States, Africa, and Southeast Asia, the Pacific Islands, parts of the Caribbean, and Central and South America (Centers for Disease Control and Prevention, 2016).

Zika infection announced as a universal general wellbeing crisis by the World Health Organization (WHO). Up until this point, tainted mosquitoes have just been found in these tropical regions of the world. Just 20 percent of tainted individuals create side effects, the most widely recognized of which are fever, rash, joint torment, and conjunctivitis (red eyes) which normally last from a few days to seven days. Pregnant ladies are most in danger because of the solid connection amongst Zika and the microcephaly, an inborn condition bringing about littler brains and heads than normal, given the expansion in intrinsic inconsistencies and other neurological and immune system disorders (European Centre for Disease Prevention and Control (ECDC), 2016).

The first Zika fever outbreak indicated in the Federated States of Micronesia In 2007. Subsequent infections of Zika Virus (Zika V) were not reported until 2013 when an outbreak occurred in French. In May 2015, for the first time, ZIKV appears in America. What's more, 58 nations and regions announced proceeding with the mosquito-borne transmission of ZIKV in the ahead of schedule of May 2016, On 22 Walk 2016 Zika detached from a 2014 blood test of an elderly man in Chittagong in Bangladesh. Zika is likewise happening in Tanzania starting at 2015/2016. Between August 2016 and November 2016455 instances of Zika infection contamination 
were affirmed in Singapore. In 2017, Angola revealed two instances of Zika fever (World Health Organization (WHO), 2017).

ZIKV infection has been mainly associated with microcephaly and other central nervous system birth defects. In addition, ZIKV infection was also associated with Guillain-Barre Syndrome (Samarasekera \& Triunfol, 2016).

There is no medicine or vaccine to cure Zika. Mosquito bites persist the main mode of transmission of Zika. When going to nations where infections have been accounted for, the best securities are a creepy insect repellent, long sleeves, and jeans, and spots with aerating and cooling or that utilize window and entryway screens (National Center for Emerging and Zoonotic Infectious Diseases (NCEZID), 2017).

Individual defensive practices have for some time been appeared to be the best technique for avoiding general wellbeing messages that embrace individual defensive practices additionally diminish the chance of risk. This study evaluates the effect of an educational program on the Knowledge, attitude, and practice of women at child bearing period about Zika Virus Infection (World Health Organization, 2016).

Zika virus has emerged as a public health issue. PAHO/WHO (Pan American Health Organization/World Health Organization) has made recommendations aimed at healthcare facilities related to strengthening capacity and specialized care. Effective strategies to prevent and control the virus, such as mosquito vector control and education of the public, are encouraged. The public health nurse had an important role in health education, health promotion, and health surveillance to identify, prevent, and manage Zika virus. Nurses have responsibility to keep currency with the evolving body of knowledge about the infection in order to provide optimal patient care (Yakob, \& Walker, 2016).

Public health nurse as an advocator has significant influence to change patients' health behaviours. Nurses should notice early symptoms of infection and thus make an important contribution to help recognize and report outbreak situations. It is nurse help control the spread of this virus. In endemic/pandemic situations, community education is vital. People ill from Zika exposure require nursing care as plentiful rest and fluids, and treatment for pain and fever with common analgesic/antipyretic medicines as the doctor ordered (Wilson, \& Nguyen, 2017).

As a counsellor public health nurse plays a significant role in providing counselling. Engaging sex partners in discussions can help so that both persons understand the benefit of delaying pregnancy and are active and positive participants in safer sex to achieve disease prevention (Gould, 2013).

\section{The Significance of the Study}

A sudden and dangerous ascent of a ZIK V flare-up seen in mid-2016 in the predominant piece of Latin American and Caribbean countries, with evaluated instances of 440,000-1,300,000 in Brazil alone. Following this scourge, ZIKV announced as a general wellbeing crisis of universal worry by WHO Since January 2007, ZIKV transmission has accounted for in a sum of 64 nations and domains. In view of a developing collection of preparatory research, there is a logical accord that ZIKV will probably keep on spreading to new zones. The wide geographical distribution of the type of mosquitoes that can be transmitted and Lack of vaccines and reliable diagnostic tests are a matter of concern. It was associated with a high incidence of neurological complications and fetal CNS Distortions (Centers for Disease Control and Prevention, 2017).

ZIKV infection has potential to cause a pandemic so it becomes a major public health concern worldwide. Despite that its impact on grown-ups is for the most part gentle, Zika postures huge wellbeing dangers for creating babies in women who wind up contaminated amid pregnancy. Subsequently, ladies of conceptive age (who are the focal point of this exploration brief) are a key target for aggregate general wellbeing endeavors to Zika virus (Adele, Emily, Brigette, Genevieve, \& Kenney, 2017). The Crisis Advisory group under the Worldwide Wellbeing Controls in its fifth gathering with respect to microcephaly prescribed that is one of the long haul readiness and reaction arranging of nations are measures to forestall ZVD in pregnant ladies.

WHO expert meetings have identified lack of awareness about ZIKaV, WHO has released the resource information pack of knowledge, practice and attitudes survey for Zika illness and possible complications. The ladies of childbearing age are an imperative populace for focusing of Zika-related general wellbeing informing messaging (World Health Organization, 2016).

World Health Organization has stressed on the requirements to give genuinely necessary instruction to groups about the preventive measures and potential difficulties related to Zika infection. The goals of this study were to improve the awareness of ZIKV infection among women at childbearing period at Benha city. 


\section{Aim}

To examine the impact of Zika Virus Infection educational program for pregnant women on their knowledge, attitude and practice before and after applying for the program.

\section{Research Hypothesis}

The program will improve the knowledge, attitude, and practice of pregnant women toward ZIKA virus.

\section{Methodology}

\subsection{Research Design}

The design used in this study was quasi-experimental research design. The main aim of using this design is to prove the causality between an intervention and an outcome.

\subsection{Setting}

Antenatal clinics affiliated to Benha Health Center were used to do this study.

\subsection{Sample}

The total number of women attended to the antenatal unit at Benha Health Center the previous month was 143 women (Benha maternal and child health care center, 2016). So, expected number of study subjects calculated by the following formula (Yamane, 1967) be105 women.

$$
n=\frac{N}{1+N(e)^{2}}
$$

Where: $\mathrm{e}=$ margin error $(0.05) \mathrm{N}=$ population, $\mathrm{n}=$ sample size, A Simple random sample of 105 pregnant women included in the study.

\subsection{Tools for Data Collection}

\subsubsection{Two Tools for Data Collection}

\section{1-A structured questionnaire (Pre-post-test)}

The tools designed by the researcher after reviewing of available review of the literature as well as similar researches. The tools designed to cover the aims and test the study hypothesis. WHO for designing and implementing KAP surveys for ZVD was considering in preparing it. This tool designed mainly to collect data related to:

The women's' socio demo graphic data level of knowledge about Zika before and after the program such as (definition, signsand symptoms, complications, and nursing management of ZV ...etc). Practice about zika virus and attitude toward zika virus.

\section{2-Program Handout}

The handout was prepared for pregnant women and included information about ZV to improve their knowledge. It also covered the definition, etiology, symptoms, complications of the mothers and fetus, diagnosis and management of ZV.

\subsubsection{Scoring System}

Knowledge: For the knowledge items, a correct response was scored 2 and the incorrect 1. For each area of knowledge, the scores of the items were summed-up and the total divided by the number of the items, giving a mean score for the part. These scores were converted into a percent score, and means and standard deviations were computed. Knowledge was considered good if the percent score was $60 \%$ or more and average between $40-60 \%$, and poor if less than $40 \%$.

\subsubsection{Content Validity and Reliability}

The tools of data collected were sent to three specialized university professors according to their comments modifications were considered.

\subsubsection{Pilot Study}

A pilot study was carried out on $10 \%$ of the total sample. It involved ten pregnant women to test the applicability and clarity of the study tools and accordingly the necessary modification was done in form of adding or omission of some questions. The nurses involved in the pilot were excluded from the main study sample. 


\subsubsection{Field Work}

The actual field work was carried out from August 2015 to the end of October 2015.It was carried out by the researcher for clients in the selected setting.

Phase I Preparatory Phase

The program was designed, statement of objectives and planning of program listed according to learning needs. Also, it was designed according to the information obtained from the pre- test. Application, program content, learning activities, teaching method and media were formulated into an instructional plan.

The program was developed based on the results obtained from the interviewing questionnaire as well as literature reviews.

\section{Phase II (Program Development)}

An educational program for the clients' designed based on the baseline data collection in phase I. The program was aiming to improve the knowledge and practice of clients' toward Zika virus. In designing the program, different and suitable teaching methods were considered (lectures/ discussion, Presentation, Group discussion, demonstration). Suitable teaching aids were specially prepared for the program application as colour posters, lab top $\mathrm{CD}$, and hand outs.

\section{Phase III (Program Implementation)}

Before implementing the program, field visits to the selected setting to explain the nature and purpose of the study, as well to discuss the plan of work to make sure their cooperation.

Implementation of the program took 2 months in addition to 2 weeks for the pre-test. The teaching time was 6 hours. The program carried out in 6 sessions. The sessions were 2-3 days/ week. The hand-out was distributed to all clients in the first day of starting implementation of the program after explanation about the aim and objectives of the program to all clients. Each session started with a summary about the previous session and the objectives of the new one, taking into consideration the use of simple language that suite the clients levels of understanding. At the end of each session, client questions were discussed to correct any misunderstanding. Clients were informed about the time and place of the next session.

\subsubsection{Program Evaluation Phase}

The researcher evaluated the effect of the educational program on women's knowledge and practice about ZV using the same tools previously used in pre and posttest assessment.

\subsubsection{Ethical Considerations}

All clients rights were protected, clients were knowledgeable about nature of the study. They were informed that all data will be confidential and data will be used for the research purpose only. Each woman had the right to withdraw at any time.

\subsection{Statistical Design}

Data entry and statistical analysis were done using the Statistical Package for Social Science (SPSS) computer program version13 on IBM compatible computer. Descriptive statistics were applied e.g. (mean, standard deviation, frequency and percentage). Tests of significance used were (t. test \& Chi. square). McNamara test was used.A significant level value was considered when $p$-value $<0.05$ and a highly significant level value was considered when $\mathrm{p}$-value $<0.001$. Data were presented using descriptive statistics in the form of frequencies, percentages for qualitative variables and means and standard deviation for quantitative variables. 


\section{Results}

Table 1. Frequency distribution of personnel characters' of studied women $(\mathrm{n}=105)$

\begin{tabular}{|c|c|c|}
\hline personnel characteristics' & Frequency & $\%$ \\
\hline \multicolumn{3}{|l|}{ Age in years } \\
\hline Less than 20 years & 22 & 21.0 \\
\hline $20<30$ & 29 & 27.6 \\
\hline $30<40$ & 41 & 39.0 \\
\hline $40-50$ & 13 & 12.4 \\
\hline Mean \pm SD & \multicolumn{2}{|c|}{$27.58 \pm 8.26$} \\
\hline \multicolumn{3}{|l|}{ Educational qualification } \\
\hline Illiterate & 17 & 16.2 \\
\hline Basic education & 6 & 5.7 \\
\hline Secondary education & 45 & 42.9 \\
\hline Higher education & 5 & 4.8 \\
\hline Postgraduate & 32 & 30.5 \\
\hline \multicolumn{3}{|l|}{ Occupation } \\
\hline Yes & 54 & 51.4 \\
\hline No & 51 & 48.6 \\
\hline \multicolumn{3}{|l|}{ Residence } \\
\hline Urban & 44 & 41.9 \\
\hline Rural & 61 & 58.1 \\
\hline
\end{tabular}

Table 1 indicates the distribution of personal characteristics' of the studied women. The mean age was $(27.58 \pm 8.26)$ years, $54 \%$ of them are working women, and $61 \%$ of them reside in rural area.

Table 2. Distribution of environmental characteristics of the studied women $(\mathrm{N}=105)$

\begin{tabular}{lcccc}
\hline & Yes & No \\
& No & $\%$ & No & $\%$ \\
\hline There is trees in or around the house & 73 & 69.5 & 32 & 30.5 \\
There is a separate kitchen & 19 & 18.1 & 86 & 81.9 \\
Proper ventilation & 105 & 100 & 0 & 0 \\
Proper water supply & 86 & 81.9 & 19 & 18.1 \\
There are birds or animals in the house & 70 & 66.7 & 35 & 33.3 \\
Separate place for these birds/animals & 10 & $15 \%$ & 60 & $85 \%$ \\
\hline
\end{tabular}

Table 2 shows the environmental characteristics of the studied women it reveals that $73 \%$ of studied women have a garden or trees in or around the house, and all studied women have proper ventilation, about $86 \%$ have a separate kitchen. About $66.7 \%$ of them have birds or animal in their house and the majority of them haven't a separate place for these animals. 
Table 3. Mean score of zika virus related knowledge among studied women $(\mathrm{n}=105)$

\begin{tabular}{|c|c|c|c|c|c|}
\hline Knowledge & Score & $\begin{array}{l}\text { Pre-intervention } \\
\text { Mean } \pm \text { SD }\end{array}$ & $\begin{array}{l}\text { Post-intervention } \\
\text { Mean } \pm \text { SD }\end{array}$ & $\begin{array}{l}\text { Paired } t \\
\text { test }\end{array}$ & P value \\
\hline Meaning of zika virus & 1 & $.5288 \pm .50158$ & $.9231 \pm .26776$ & 6.547 & .000 \\
\hline Causative agent of zika virus & 1 & $.5048 \pm .50238$ & $.9619 \pm .19234$ & -8.437 & .000 \\
\hline Risk factors of zika virus & 5 & $1.8476 \pm 1.12473$ & $3.7714 \pm .91207$ & -12.531 & .000 \\
\hline Mode of transmission of zika virus & 4 & $1.1143 \pm 1.11212$ & $2.4571 \pm 1.12685$ & -8.953 & .000 \\
\hline Most susceptible to the disease & 1 & $.1429 \pm .35161$ & $.7048 \pm .45834$ & -10.748 & .000 \\
\hline Complication of Zika virus & 4 & $1.1905 \pm .79778$ & $2.6190 \pm .83644$ & -11.963 & .000 \\
\hline Symptoms' of Zika virus & 8 & $3.3238 \pm 1.61421$ & $6.7429 \pm 1.04724$ & -17.569 & .000 \\
\hline Vaccine of Zika virus & 1 & $.3905 \pm .49020$ & $.7238 \pm .44926$ & -5.063 & .000 \\
\hline Treatment of zika virus & 1 & $.3048 \pm .46251$ & $.6857 \pm .46646$ & -5.950 & .000 \\
\hline Preventive measures & 7 & $3.8571 \pm 1.36880$ & $4.6095 \pm 1.48386$ & -3.668 & .000 \\
\hline Precaution when using pesticides & 5 & $1.9905 \pm 1.14770$ & $4.2857 \pm .74310$ & -18.087 & .000 \\
\hline Total knowledge & 33 & $15.2000 \pm 4.35758$ & $28.4667 \pm 3.60573$ & -22.753 & .000 \\
\hline
\end{tabular}

Table 3 manifests highly statistically significant difference of studied women knowledge about Zika virus pre/ post program, with the highest mean score regarding their knowledge about the availability of Zika virus vaccine.

Table 4. Mean score of Zika virus of studied women's reported practices $(\mathrm{n}=105)$

\begin{tabular}{lllrr}
\hline Practice & $\begin{array}{l}\text { Pre-intervention } \\
\text { Mean } \pm \text { SD }\end{array}$ & $\begin{array}{l}\text { Post-intervention } \\
\text { Mean } \pm \text { SD }\end{array}$ & $\begin{array}{l}\text { Paired t } \\
\text { test }\end{array}$ & P value \\
\hline Use of fans to expel mosquitoes & $.5905 \pm .63086$ & $1.5429 \pm .57225$ & -9.632 & .000 \\
Using curtains for windows & $.5048 \pm .65227$ & $1.6476 \pm .53675$ & -12.012 & .000 \\
Use bed mosquito net & $.6857 \pm .60945$ & $1.4857 \pm .55668$ & -8.497 & .000 \\
Wear long sleeves clothes & $.5810 \pm .67626$ & $1.6667 \pm .47367$ & -11.333 & .000 \\
Use of insecticide for mosquito & $.6476 \pm .63520$ & $1.5905 \pm .49410$ & -9.970 & .000 \\
Cleaning the house and its & $.4857 \pm .63722$ & $1.6667 \pm .47367$ & -12.246 & .000 \\
surroundings & $.4381 \pm .60326$ & $1.7524 \pm .43370$ & -14.756 & .000 \\
Daily Garbage disposal & $3.9333 \pm 2.26710$ & $11.3524 \pm 1.25561$ & -27.015 & .000 \\
Total practice & & &
\end{tabular}

Table 4 displaysa highly statistically significant difference of studied women practice about Zika virus pre/ post program, the highest mean score was use of bed mosquito net followed by using insect side.

Table 5. Mean score of Zika virus related attitude among studied women

\begin{tabular}{lllrr}
\hline Attitude & $\begin{array}{l}\text { Pre-intervention } \\
\text { Mean } \pm \text { SD }\end{array}$ & $\begin{array}{l}\text { Post-intervention } \\
\text { Mean } \pm \text { SD }\end{array}$ & $\begin{array}{l}\text { Paired t } \\
\text { test }\end{array}$ & $\begin{array}{l}\text { P } \\
\text { value }\end{array}$ \\
\hline $\begin{array}{l}\text { Is the disease deadly } \\
\begin{array}{l}\text { Are you afraid to travel to infected } \\
\text { places }\end{array}\end{array}$ & $.6762 \pm .61230$ & $1.4762 \pm .50183$ & -8.327 & .000 \\
$\begin{array}{l}\text { Do you think that pregnant women } \\
\text { are more likely to get the disease }\end{array}$ & $.6190 \pm .71227$ & $1.6476 \pm .48000$ & -10.494 & .000 \\
$\begin{array}{l}\text { Are you interested in following the } \\
\text { news of the disease }\end{array}$ & $.4000 \pm .65925$ & $1.7905 \pm .40892$ & -15.403 & .000 \\
$\begin{array}{l}\text { Do you think that awareness and } \\
\text { health education are adequate }\end{array}$ & $.5714 \pm .66299$ & $1.6190 \pm .48795$ & -10.696 & .000 \\
$\begin{array}{l}\text { Do you care about the means of } \\
\text { prevention against the disease }\end{array}$ & $.6381 \pm .65227$ & $1.5524 \pm .49963$ & -9.358 & .000 \\
$\begin{array}{l}\text { Do you think that the disease will } \\
\text { spread very quickly in the world }\end{array}$ & $.5619 \pm .66396$ & $1.6286 \pm .48550$ & -10.902 & .000 \\
$\begin{array}{l}\text { If there is vaccination against the } \\
\text { disease, will you take it }\end{array}$ & $.4857 \pm .60629$ & $1.6286 \pm .48550$ & -11.776 & .000 \\
\begin{tabular}{l} 
Total attitude \\
\hline
\end{tabular} & $4.3333 \pm 3.41565$ & $13.1333 \pm 1.56320$ & -22.786 & .000 \\
\hline
\end{tabular}


Table 5 shows that there was a highly statistically significant difference of studied women attitude about Zika virus pre/post program. The disease ability to cause death, fear of traveling to an infected place and care about prevention measures have the highest score.

Table 6. Correlation between total knowledge, attitude\& practice score pre and post intervention of the studied women

\begin{tabular}{lcccccccc}
\hline & \multicolumn{2}{c}{ Practice } & \multicolumn{2}{c}{ attitude } & \multicolumn{3}{c}{ Practice } & \multicolumn{3}{c}{ attitude } \\
& pre-intervention & \multicolumn{2}{c}{ pre-intervention } & \multicolumn{2}{c}{ post-intervention } & \multicolumn{2}{c}{ post-intervention } \\
& $\mathrm{r}$ & $\mathrm{P}$ & $\mathrm{r}$ & $\mathrm{P}$ & $\mathrm{r}$ & $\mathrm{P}$ & $\mathrm{r}$ & $\mathrm{P}$ \\
\hline Knowledge pre-intervention & -.155 & .114 & $-.245^{*}$ & .012 & - & - & - & - \\
Knowledge post-intervention & - & - & - & - & .026 & .792 & .030 & .763 \\
\hline *. Correlation is significant at the 0.05 level (2-tailed). & & & & & \\
**. Correlation is significant at the 0.01
\end{tabular}

Table 6 shows a correlation between total knowledge, practice and attitude score of the sample pre and post intervention it displays that there is a significant correlation between the knowledge and the attitude of participants pre-test.

Figure 1 shows that there was a highly statistically significant difference regarding studied women knowledge about Zika virus pre/ post program.

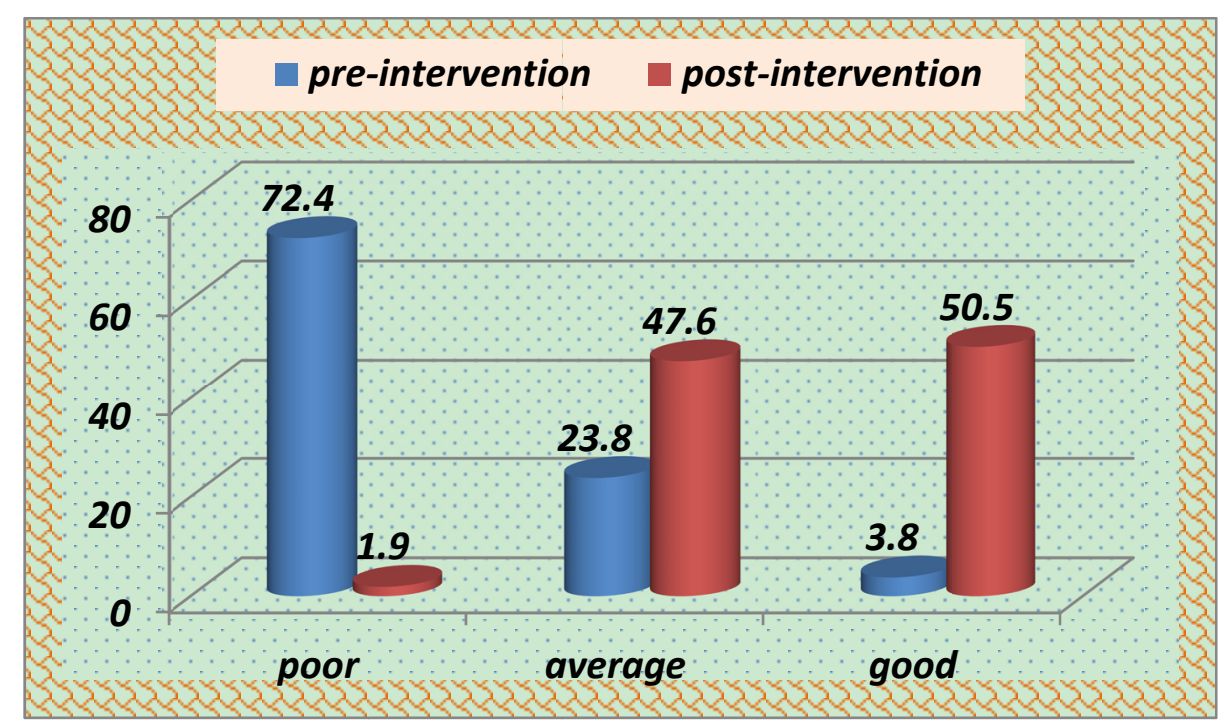

Figure 1. Total knowledge pre and post intervention

Figure 2 shows that there was a highly statistically significant difference regarding studied women practice regarding Zika virus pre/ post program. 


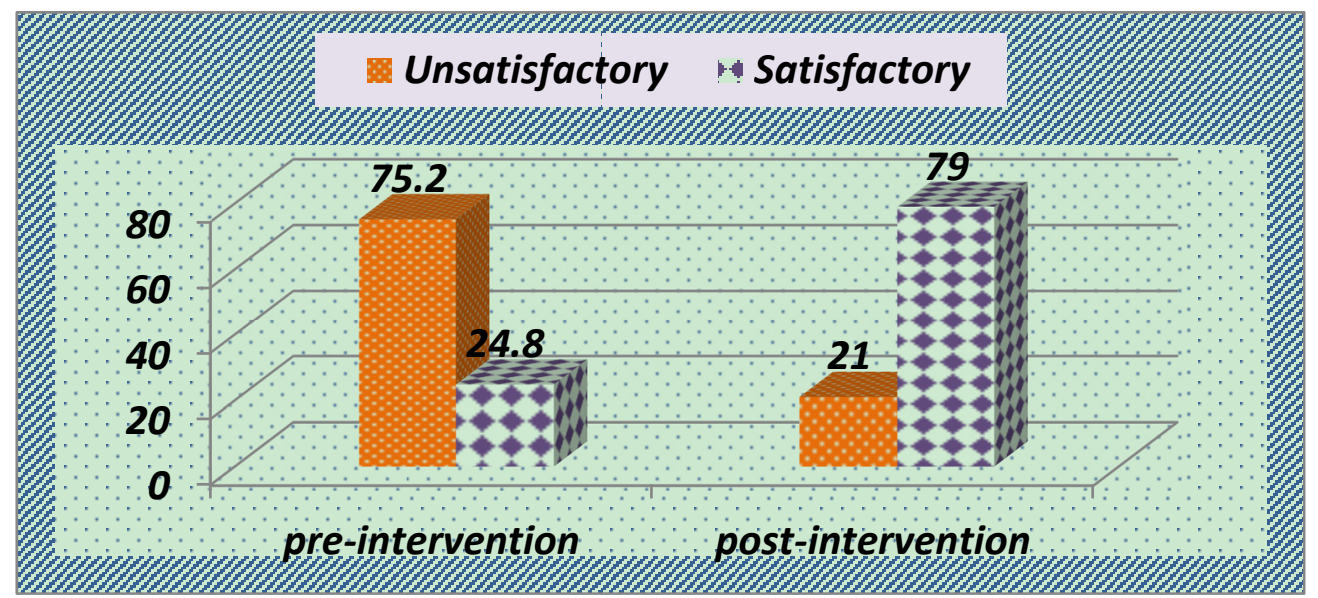

Figure 2. Total practice pre and post intervention

Figure 3 shows that there was a highly statistically significant difference regarding studied women attitude regarding Zika virus pre/ post program.

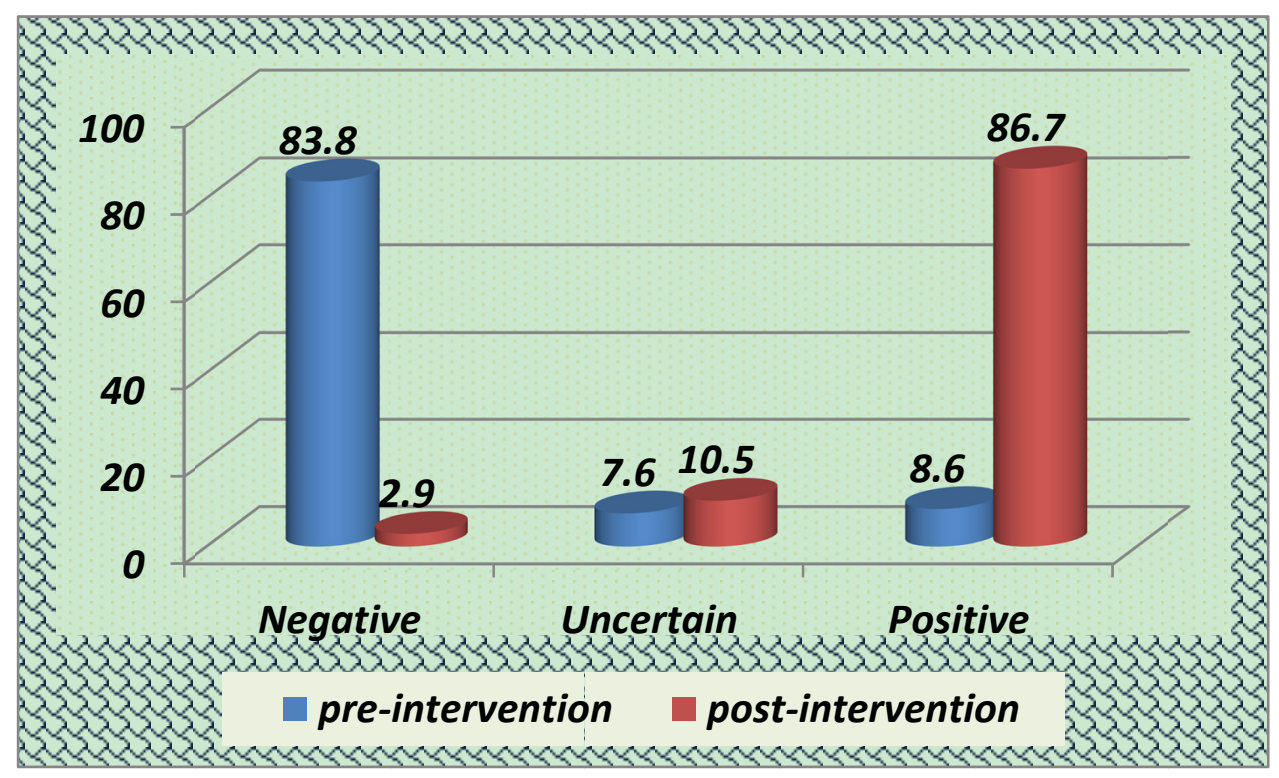

Figure 3. Total attitude pre and post intervention

\section{Discussion}

Our study aimed to evaluate the effect of the educational program on pregnant women's Knowledge, attitude and practice of women at child-bearing period about Zika Virus Infection. This aim achieved through the present study findings. According to the results yielded by the present study the mean age of studied women were (27.58 \pm 8.26$)$ years, Zika has critical wellbeing dangers for fetuses of women who become infected during pregnancy. Therefore, ladies of regenerative age are a key target aggregate for public health efforts to address Zika virus. majority of participants live in rural area where the breeding site of mosquitoes like open wells and drains were significant more indicating poorer containment measures by people residing in these areas. Similarly, absence or less frequent spray operations seem significantly more in rural areas indicates poorer government response. Considering the environmental characteristics of studied women, the results of current study showed that majorly of studied women have a garden or trees in or around the house, and all studied women have proper ventilation, More than two third of them have birds or animal in their house and majority of them haven't a separate place for these animals.

According to National Environmental Health Association (NEHA) Environmental characteristics have a meaningful role in the prevention and control of mosquito-borne infection. It has an important task in the 
elimination of mosquito breeding grounds. Investigations and inspections for the environment provide an opportunity to intervene if there are issues like standing water, or containers or debris that could house standing water and create a habitat for mosquito larvae. Environmental and public health professionals can improve the consciousness around our role in mosquito control which will decrease the chances of mosquito-borne diseases like Zika.

Whitehouse fact sheet 2016 has focused attention on the environmental man-made factors partially responsible for the spread of the disease. The mosquito doesn't live in swamps or in the ground like others of its kind, but has adapted to the world of humans-somewhat like a human parasite. It thrives and grows in artificial habitats such as water containing containers, plastic containers, around which used in bird breeding, trees and irrigation system and other water-collecting refuse. House waste, improper sanitation and inadequate ventilation is a major contributor to the insect's ability to reproduce.

As regards to women knowledge about Zika infection such as, (meaning of Zika, causative agent, mode of transmission complication, treatment and vaccine), the present study revealed that about three quarters of participants had poor knowledge before the program (Figure one). These findings are consistent with the study of (Harapan, Alma, Samsul, \& Abdul,2017) in which the studied sample had poor knowledge about Zika virus, these finding also come in agreement with the study of Shartzer, 2016 who found that there were sizable gaps in knowledge of women in reproductive age about Zika virus. The explanation of this poor knowledge is Zika infection is a new emerging infectious disease and therefore it has not been included in the medical or nursing curriculum even in media and public health practitioner. The bridging knowledge gap is vital in the planning of educational programs to increase the community know about the disease.

As regard to participant practice the results of this study indicate that slightly more than three-quarters of participants have unsatisfactory practice toward preventing Zika virus and other mosquito-transmitted diseases. In the present study, all participants were using one or other mosquito bite prevention methods it is similar to (Taís, \& David, 2017) who found that $51.8 \%$ claimed to always do some prevention measures in their daily basis Use of bed mosquito net was the most frequently reported method of prevention, followed by using insect side, Heitzinger2017 (Kristen, Douglas, Thorough, \& Kimberly, 2017) conducted a phone-based survey about Knowledge, Attitudes, and Practices of Women of Childbearing about Zika Virus in Kentucky and identified that two-thirds of the respondents reported taking action to prevent Zika infection while travelling or living in a Zika-affected area; use of mosquito repellent was the most frequently reported method of prevention (53\%), followed by wearing protective clothing (18\%). In accordance with Wasnik, 2017 (Sumit, \& Arjun, 2017) found that more than half of participants prevent mosquito bites by using repellents and near half of them use the tablet to keep mosquitoes away or mosquito coil or repellent liquid vaporizers.

Considering the clients' attitude, the study showed a highly statistically significant of studied women attitude about Zika virus pre/ post program. The disease ability to cause death, fear of travelling to an infected place and care about prevention measures have the highest score. Heitzinger, 2017 found in his study that early two thirds of the studied sample reported taking act to avoid Zika infection while existing in a Zika-affected region or travelling. The finding of the current study indicates that about 83.1 of participant have a negative attitude pre-test this is Uncomplicated with Arief et al 2017 (Mohammad et al., 2017) who found that (70.9\%) of sample has a favourable attitude, too.

According to research finding our hypothesis the health education program improves the knowledge, practice and attitude of pregnant women regarding Zika virus was proved. this in the same line with by tram, et al 2003 (Tran et al., 2003) who reported that The role of education on such these diseases was to educate individuals of accessible logical learning of the disease, so they could utilize this information to achieve a change of states of mind and practices for better wellbeing. Instruction expanded their comprehension of the issue and empowered their investment in counteractive action and control measures against these irresistible diseases. Health training had a solid effect on the moms' information, state of mind and practice about mosquito conceived maladies as dengue fever.

Our data revealed a significant correlation between the knowledge and the attitude of participants pre-test. And an insignificant correlation between knowledge and practice in the literature knowledge and attitude scores has not always been found to predict practice scores. Knowledge and attitude scores did not predict practice score on KAP towards osteoporosis among a sample of Malaysian university students (Khan, Sarriff, Khan, \& Mallhi). However, higher knowledge score was found to be a strong predictor of higher attitude and practice scores among military servicemen about swine flu in Singapore (Yap, Lee, Yau, \& Tor). 
The insignificant correlation between knowledge and practice may be due to the absence of zika cases in Egypt or due to lack of the educational program about the disease and insufficient health messages provided to people especially women during pregnancy.

\section{Conclusion}

The study concluded that there were insufficient knowledge, attitude and practice of pregnant women before the educational program. There was an improvement in their knowledge, attitude and practice of the participants post-program.

\section{Recommendation}

Health education to pregnant women about the zika virus should be included in the antenatal health education program.

The necessity for extra public health communications emphasizing on the method of transmission and preventing measures of the virus.

The health educational programs about zika virus should be implemented in another setting and the health workers should take apart of these programs.

\section{Limitation of the Study}

The study had the following limitation:

The evaluation of attitudes and practices toward zika virus has relied on self-reported data collected through interviews and could potentially be affected by social desirability bias.

Lack of researchers and literature that discuss Zika infection. However, despite these limitations, our findings indicate that the educational program was effective in improving the knowledge, attitude and practice of pregnant women.

\section{References}

Adele, S., Emily, J., Brigette, C., Genevieve, M., \& Kenney, A. (2017). Cross-sectional Survey on the Knowledge and Attitudes towards Zika Virus and its Prevention among Residents of Selangor, Malaysia. Journal of Pharmacy Practice and Community Medicine, 3(2), 81-89.

Benha maternal and child health care center census. (2016).

Centers for Disease Control and Prevention. (2016). Facts about microcephaly. Retrieved February 4, 2016, from http://www.cdc.gov/ncbddd/birthdefects/microcephaly.html

Centers for Disease Control and Prevention. (2017, December). Prevention of mosquito-borne transmission. Retrieved from https://www.cdc.gov/zika/reporting/2017-case-counts.html

European Centre for Disease Prevention and Control (ECDC). (2016). Zika Virus Disease Epidemic: Preparedness Planning Guide for Diseases Transmitted by Aedesaegypti and Aedesalbopictus. ECDC. Stockholm, Sweden4. Retrieved February 4, from http://ecdc.europa.eu/en/publications/Publications/rapid-risk-assessment-zika-virus-first-update-jan-2016.pdf

Gould, D. (2013). Outbreaks of infection in community settings: The nursing implications. Primary Health Care, 23(3), 32-40. https://doi.org/10.7748/phc2013.04.23.3.32.e750

Harapan, H., Alma, A., Samsul, A., \& Abdul, M. (2017). Healthcare workers' knowledge towards Zika virus infection in Indonesia: A survey in Aceh. Asian Pacific Journal of Tropical Medicine, 10(2), 189-194.

Khan, Y., Sarriff, A., Khan, A., \& Mallhi, T. (2014, January). Knowledge, Attitude and Practice (KAP) Survey of Osteoporosis among Students of a Tertiary Institution in Malaysia. Tropical J of Pharmaceutical Research, 13(1), 155-162. https://doi.org/10.4314/tjpr.v13i1.22

Kristen, H., Douglas, A., Thorough, M., \& Kimberly, A. (2017). Knowledge, Attitudes, and Practices of Women of Childbearing Age Testing Negative for Zika Virus in Kentucky. Retrieved June 6, 2017, from https://cste.confex.com/cste/2017/webprogram/Paper7473.html

Mohammad, A., Mohamed, A., Ahmad, H., Fahad, S., Muhammad, U., Akram, A., Akshaya, S., \& Shazia, Q. (2017). A Cross-sectional Survey on the Knowledge and Attitudes towards Zika Virus and its Prevention among Residents of Selangor, Malaysia. Journal of Pharmacy Practice and Community Medicine, 3(2), 81-89. https://doi.org/10.5530/jppcm.2017.2.20

National Center for Emerging and Zoonotic Infectious Diseases (NCEZID). (2017). Retrieved 26 April, 2017, 
from https://www.cdc.gov/ncezid/

Samarasekera, U., \& Triunfol, M. (2016, February). Concern over Zika virus grips the world. Lancet, 387(10018), 521-524.

Sumit, W., \& Arjun, M. (2017, October). Awareness, knowledge and practices about mosquito borne diseases in patients of tertiary care hospital in Navi Mumbai. International Journal of Community Medicine and Public Health, 4(10), 3673.

Taís, P., \& David, C. (2017). Pregnant awareness about zika virus infection during pregnancy. Brazilian Journal of Medicine and Human Health, 5(4), 1085-1087.

The National Environmental Health Association (NEHA). (2018). Environmental Health Programs and Zika. Retrieved from https://neha.org/zika 28/1/2018.

Tran, T., Nguyen, T., Nguyen, T., Nguyen, T., Le, T., Nguyen, P., \& Le T. (2003). The Impact of Health Education on Mother's Knowledge, Attitude and Practice (KAP) of Dengue Hemorrhagic Fever. Dengue Bulletin 27.

White house fact sheet. (2016). from https://obamawhitehouse.archives.gov/the-press-office/2016/02/08/fact-sheet-preparing-and-responding-zik a-virus-home-and-abroad

Wilson, A., \& Nguyen, T. (2017). The Zika Virus Epidemic: Public Health Roles for Nurses. OJIN: The Online Journal of Issues in Nursing, 22(1).

World Health Organization (WHO). (2017, November). The History of Zika Virus. Retrieved from http://www.who.int/emergencies/zika-virus/history/en/

World Health Organization. (2016). Knowledge, Attitudes and Practice Surveys. Zika Virus Disease and Potential Complications, Resource Pack. Geneva, Switzerland.

World Health Organization. (2016). Risk Communication and Community Engagement for Zika Virus Prevention and Control: A Guidance and Resource Package for Country Offices for Coordination, Planning, Key Messages and Actions. World Health Organization; Geneva, Switzerland.

Yakob, L., \& Walker, T. (2016). Zika virus outbreak in the Americas: The need for novel mosquito control methods. The Lancet Global Health, 4(3), 148-149. https://doi.org/10.1016/S2214-109X(16)00048-6

Yamane, T. (1967). Statistics an Introductory Analysis (2nd ed.). New York Harper and Row CO.USA.213.

Yap, J., Lee, V., Yau, T., \& Tor, P. (2010). Knowledge, attitudes and practices towards pandemic influenza among cases, close contacts, and healthcare workers in tropical Singapore: a cross-sectional survey. BMC Public Health, 10, 442. https://doi.org/10.1186/1471-2458-10-442

\section{Female Aedes Aegypti Mosquito}

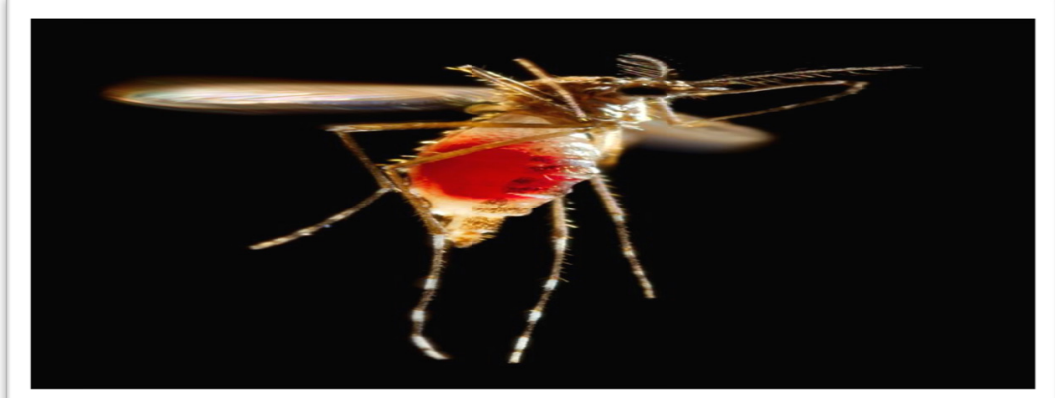

\section{Copyrights}

Copyright for this article is retained by the author(s), with first publication rights granted to the journal.

This is an open-access article distributed under the terms and conditions of the Creative Commons Attribution license (http://creativecommons.org/licenses/by/4.0/). 